\title{
THE PROSPECTS FOR ECOSYSTEM SERVICES PROVISION IN FRAGILE STATES' URBAN AREAS
}

\author{
Antonija BOGADI
}

\begin{abstract}
In fragile states context of climate change vulnerability, poverty and lack of infrastructure, the ability of ecosystem services to provide for numerous human needs is indispensable. The focus of this paper is describing the prospects for ecosystem services provision in fragile states' urban areas. This paper presents a distinct approach by analyzing actors with capacity to provide ecosystem services in urban areas: government, international partners and citizens. Using infrastructure investments data from Asian Development Bank, African Development Bank and World Bank, obstacles for ES provision are related to weak and fragmented governments, non-transparency and low access to international funds and insufficient involvement of citizens. The work presented here argues for ecosystem services implementation as a valid part of solution for fragile states' difficulties and has implications for future studies of governance measures for providing ecosystem services in urban areas.
\end{abstract}

Keywords: actors; climate change; ecosystem services; urban areas

\section{INTRODUCTION}

A few tens of countries in the world are confronting extreme, internally and externally caused difficulties in their development. Those countries are called "fragile states" and they are mostly dealing with rapid population growth combined with high population density, climate change, low economic and social resilience, government instabilities often linked with internal and external conflicts [1].

The most serious predicted climate change impacts in fragile countries are extremes of precipitation and temperature, more frequent and intense storms, and sealevel rise. When this is combined with the issues stated above, it is clear that fragile states are countries most vulnerable to climate changes. Those areas are already struggling with problems connected to climate change and it is most probable that these will worsen in the future.

According to recent thinking, ecosystem-based adaptation concept is seen as one of the answers for adapting to the emerging and irreversible impacts of climate change. The advantage of ecosystem-based adaptation is that it generates various additional co-benefits, such as climate change mitigation, food provision, and increasing environmental knowledge. Moreover, it is cost-effective alternative or a complement to traditional, engineeringbased approaches. The premise of this article is that such a multi-beneficial intervention could be a proper, satisfactory way for climate change adaptation in fragile countries.

As the need for carefully managed ecosystems mostly occurs in the cities [2], due to the variety of actors and conflicting interests, the focus of this paper is to describe the circumstances in ecosystem services provision in fragile states' urban areas.

Governance measures used to provide ecosystem services in cities elsewhere in the world are not effective in the context of fragile states, because different stakeholders are involved and governments are fragmented and too weak to carry out major responsibilities for their implementation.
The role of international development partners with their funding and knowledge is an important factor, but the access to those resources is often nontransparent and overly politically conditioned. It appears that the best strategy for ecosystem services implantation in urban areas is a switch to long-termed political actions, introducing policies focused on city-wide impacts, implementing combination of regulating, provisioning and cultural ecosystem services, and good cooperation with local communities in using local knowledge and practices.

\section{FRAGILE STATES AND VULNERABILITY TO CLIMATE CHANGE}

The Fund for Peace Fragile States Index is an annual ranking of 178 countries based on their levels of stability and threats [3]. Every country is ranked based on the key political, social and economic fragility indicators developed from social science research.

Sixty countries with the highest fragility are considered "fragile". World Bank estimates that more of the quarter of world's population lives in fragile states, with a majority of people surviving on less than US\$1.25 per day, highest rates of children dying before the age of five, and highest maternal deaths rates [4].

The gap between fragile sates and other developing countries is widening and projections show that fragile states will constitute an even larger share of low-income countries [4]. This is a world's major sustainable development issue and development models for narrowing the gap need to be fundamentally different than in other countries due to the different context of risks.

Due to the combination of frequent natural disasters, high population density and low resilience to economic shocks fragile sates are expected to be worst affected by climate change.

Tab. 1 compares the country's fragility rank from The Fund for Peace's Fragile States Index and a country's 
vulnerability rank to climate change from The Centre for Global Development $[3,5]$.

The countries are ranked according to vulnerability to changes in extreme weather, vulnerability to changes in sea level rise, overall climate change impact only from climate drivers, and vulnerability to climate change from climate drivers plus economic development and governance [5].

Tab. 1 demonstrates the ranks of 20 countries which are most vulnerable to those categories. When the fragility rank (shown in brackets) is added to the country's rank, it is clear that the countries suffering from overall climate change impact only from climate drivers (with no socio-economic drivers) and vulnerability to climate change impacts from climate drivers and socio-economic drivers are also fragile states.
The share of fragile states in the 20 countries most vulnerable to changes in extreme weather and changes in sea level rise is not significant, because only population at risk and the probability of extreme weather and sea level rise are measured and defined as vulnerability [5].

When including other factors in calculating impacts and vulnerability, like urge for changing the residence, agricultural productivity loss, economic development and governance strength, it is obvious that fragile states are most at risk, mainly because they mostly depend on agriculture and are economically and organizationally weak. To present the strong connection between fragility and vulnerability more clearly, fragility category [3] is added to each fragile country.

Table 1 Countries' fragility rank and a country's vulnerability rank to changes in extreme weather, rise of sea level, climate change impacts form climate drivers and general climate change impacts. (Data derived from $[3,5])$

\begin{tabular}{|c|c|c|c|c|}
\hline & $\begin{array}{l}\text { Vulnerability to changes in } \\
\text { extreme weather: Population at } \\
\text { risk from changes in extreme } \\
\text { weather (rank 2015) }\end{array}$ & $\begin{array}{l}\text { Vulnerability to changes in sea } \\
\text { level rise: Population at risk } \\
\text { from sea level rise (rank 2015) }\end{array}$ & $\begin{array}{l}\text { Overall climate change impact } \\
\text { from climate drivers only: } \\
\text { extreme weather; change in the } \\
\text { probability of residence; change } \\
\text { in agricultural productivity } \\
\text { (rank 2015) }\end{array}$ & $\begin{array}{l}\text { Vulnerability to Climate } \\
\text { Change from climate drivers, } \\
\text { economic development and } \\
\text { governance (rank 2015) }\end{array}$ \\
\hline 1 & China & India & Central African Republic (3) & Myanmar (26) \\
\hline 2 & Djibouti (39) & Bangladesh (36) & Burundi (15) & Bangladesh (36) \\
\hline 5 & Somalia (1) & Philippines (54) & Rwanda (32) & Burundi (15) \\
\hline 6 & Mozambique (42) & Nigeria (13) & Senegal (59) & Vietnam \\
\hline 7 & Bangladesh (36) & Vietnam & Ethiopia (24) & Zimbabwe (16) \\
\hline 8 & Sri Lanka & Japan & Myanmar (26) & Niger (19) \\
\hline 9 & Ethiopia (24) & United States & Malawi (44) & Malawi (44) \\
\hline 10 & Vietnam & Egypt, Arab Rep.(38) & Niger (19) & Congo Rep. (31) \\
\hline 15 & Honduras & Turkey & Guniea Bissau (17) & Guinea (12) \\
\hline 16 & Thailand & Malaysia & Zimbabwe (16) & Cambodia (46) \\
\hline 17 & Zambia (49) & Germany & Congo Rep. (31) & Haiti (10) \\
\hline 18 & Colombia (67) & Italy & Vietnam & Zambia (49) \\
\hline 19 & Zimbabwe (16) & Mozambique (42) & Cambodia (46) & Senegal (59) \\
\hline 20 & China & Thailand & Guinea (10) & Guinea Bissau (17) \\
\hline
\end{tabular}

\begin{tabular}{|c|c|c|}
\hline & Fragile state rank & Fragility category \\
\hline & $1-8$ & very high alert \\
\hline & $9-16$ & high alert \\
\hline & $17-38$ & alert \\
\hline & $39-67$ & high warning \\
\hline
\end{tabular}

\section{ECOSYSTEM SERVICES AND CLIMATE CHANGE ADAPTATION}

Current discussions on cities facing the upcoming climate changes raise the understanding that cities need to be increasingly adaptable to changes, such as less foreseeable rainfall and temperature regimes [6]. Ecosystem-based adaptation concept has a potential to contribute to sustainable urban development and it is getting growing attention from academic and governmental bodies [7-11].
Ecosystem-based adaptation uses ecosystem services to help people adapt to the various effects of climate change [12]. That approach is a cost-effective alternative or a complement to traditional, engineering-based solutions, with an advantage of generating various co-benefits; among others climate change mitigation and food provision (Tab. 2). This relatively new concept could raise human resilience to climate change with natural and managed ecosystems [2], noting that the need for managed ecosystems usually occurs in the cities. 
Use of ecosystem services could provide better management of storm-water runoff, lowered incidents of combined storm and sewer overflows, water capture and conservation, flood prevention, storm-surge protection, defense against sea-level rise, accommodation of natural hazards (e.g., relocating out of floodplains), and reduced ambient temperatures and urban heat island (UHI) effects. Low levels of formal employment in fragile state cities put a high level of dependency on the provision of other ecosystem services, such as water, fuel, and food production, from areas within cities as well as nearby natural areas $[13,14]$.

In fragile states context of climate change vulnerability, poverty and lack of infrastructure, the ability of ecosystem services to provide for numerous human needs is indispensable [15].

\section{GENERAL OBSTACLES OF ECOSYSTEM SERVICES PROVISION IN URBAN AREAS}

The focus of this paper is to describe the circumstances in ecosystem services provision in fragile states' urban areas for climate change adaptation.

Fragile states are increasingly urbanizing, but those settlements are marked by extreme social inequity, weak governance structures, poor infrastructure and services delivery, limited environmental regulation, and low scientific capacity regarding ecosystem services and biodiversity, all of which impacts biodiversity loss and ecosystem services provisioning [13].

Table 2 Ecosystem services and their benefits. The Millennium Ecosystem Assessment [16] and The Economics of Ecosystem Services and Biodiversity [17] grouped ecosystem services in four categories: provisioning, regulating, habitat and cultural services.

\begin{tabular}{|c|c|}
\hline Ecosystem service & Ecosystem service benefit \\
\hline $\begin{array}{l}\text { Provisioning } \\
\text { ecosystem services }\end{array}$ & $\begin{array}{l}\text { Material products obtained gained from } \\
\text { ecosystems, including genetic resources, } \\
\text { food and fiber, and fresh water. }\end{array}$ \\
\hline Cultural services & $\begin{array}{l}\text { Non-material benefits that users receive } \\
\text { from ecosystems through spiritual } \\
\text { enrichment, cognitive development, } \\
\text { reflection, recreation, and aesthetic } \\
\text { experience, supporting knowledge } \\
\text { systems, social relations, and aesthetic } \\
\text { values. }\end{array}$ \\
\hline $\begin{array}{l}\text { Supporting or habitat } \\
\text { services }\end{array}$ & $\begin{array}{l}\text { Services necessary for the production of } \\
\text { all other ecosystem services, like biomass } \\
\text { production, nutrient cycling, water } \\
\text { cycling, provisioning of habitat for } \\
\text { species, and maintenance of genetic pools } \\
\text { and evolutionary processes. }\end{array}$ \\
\hline Regulating services & $\begin{array}{l}\text { Benefits attained from the regulation by } \\
\text { ecosystem processes, including the } \\
\text { regulation of climate, water, and some } \\
\text { human diseases. }\end{array}$ \\
\hline
\end{tabular}

Biodiversity concerns, crucial for ecosystem services provision, are often treated as less important and not relevant to other urban issues such as poverty, unemployment, and access to food, energy, water, sanitation, and housing. Where urban biodiversity interventions are carried out, they are most often neglecting multiple benefits of ecosystem services and are focusing just on single ecosystem service [13].

Geographical gap in knowledge is also an obstacle for ecosystem services provision in urban areas. Most scientific studies of ecosystem services in cities are performed and published in Europe, North America and China [18], so there is insubstantial understanding of the urban ecosystem services needs and management in large regions in South Asia, Africa and Latin America.

The economic values of ecosystem services are most often derived from conventional economic accounts (e.g. cost-benefit analysis, supply and demand relations), which are not taking in account changes in human well-being outside a market. Those effects are called environmental externalities, which can be either negative (e.g., pollution) or positive (e.g., ecosystem services).

Therefore, due to economic valuation of ecosystem services the 'hidden' economic costs of the transformation of ecological infrastructure to build infrastructure are made visible.

For example, avoided cost methods show that loss of urban vegetation can lead to bigger energy costs for cooling, loss of vegetation in the city, increase the dependence on costly water purification technologies. Likewise, lack of ecosystem services such as air purification, noise reduction, carbon sequestration and regulation of water flows also contribute to significant economic costs [19].

Regardless of abundant research of economic benefits of ecosystem services implementation, management decisions are still mainly based on economic information so ecosystem services with unclear economic value are regularly depreciated [19].

\section{ACTORS RESPONSIBLE FOR ECOSYSTEM SERVICES PROVISION}

Ecosystem services implementation policies and regulations used in developed world cannot be useful in the fragile states' context of informality and poverty. It is important to recognize the actors, understand their relationships and responsibilities in order to develop appropriate strategies for effective ecosystem services provision.

This paper identifies state bodies, international agencies and local community as most important actors. A brief analysis of their responsibilities and domains of actions is given further in the text.

\subsection{Government}

Government is the most important actor in enabling the successful ecosystem services provision, but such a role is problematic in fragile states due to their relatively low stability and capacity. Government needs to play a number of different roles in order to efficiently manage ecosystem services provision: 
- Good governance procedures should be provided both within its own institutions and between government and other actors. There is often disconnection and lack of effective communication between local and national levels of government, and between government and other actors, and failure of national policy to be implemented on the local scale.

- Correct policies and regulations should be aiming at facilitating investments in providing ecosystem services, like monitoring mechanisms for sustainable harvesting of ecosystem resources, sanctions for those harming ecosystem services implementation process, mechanisms for conflict resolutions among the actors with different interests, and controlling corruption.

- Long term commitment and planning are important in ES provision, especially for adaptation to climate change purposes and they need to be undertaken at the right time because putting investments in climate adaptation on hold may cost more in the future due to reconstruction costs, i.e. flood regulation.

\subsection{International Development Partners}

International development partners, such as international development funds, foreign embassies and export credit agencies, are crucial in financing the ecosystem services provision projects in fragile states.

The data presented here is gathered to describe the general context of financing climate change adaptation projects in fragile states that are relevant for providing ecosystem services and it originates from international development funds, mostly from World Bank Clean Investment Fund, African Development Bank and Asian Development Bank.

Many international funds are created to enable access to finance, such as the UNEPs Green Climate Fund, World Bank's Clean Investment Fund, Global Environment Facility fund, but fragile states often have trouble getting these sources [20-22]. One of the biggest sources of international finance is Global Environment Facility, which set up the Least Developed Country Fund, aimed for providing least developed countries with financial support for their climate change adaptation strategies.

Although such mechanisms should enable unconditional access to finance for least developed countries, they are regularly blocked to do so. Those mechanisms require many checks and monitoring systems regarding rigorous good governance requirements (with the intention to weaken "undesirable" regimes) which are preventing fragile states from accessing them [23].

World Bank Clean Investment Fund Expenditure and Global Environment Fund Expenditure data show that even if there is a high availability climate change adaptation financing, the percentage that goes to fragile states is low. The percentage that is destined to ecosystem based climate adaptation projects is even lower, because fragile states seem to be limited in their capacity to access international financing mechanism $[1,4]$.
Further challenges occur even when project is already funded and in implementation. The projects are often planned by the international donors, with their interests, outcomes and goals, without including the thoughts of local community or government until the evaluation stage [24].

Furthermore, the long term projects often fail after the official project end, because authorities responsible for different components of the project are not nested enough in government bodies after funding partner leaves [24, 13].

\subsection{Local Community}

It is often unclear in fragile states how the responsibilities for the ecosystem services management are divided between the various governmental bodies. In an environment with such a fragmented government, frequently the local community, local individuals and international development partners are taking over a determinant role in managing the provision of ecosystem services.

Ecological knowledge at the local level exists and it is used in informal and small scale management of urban ecosystems, as case studies of places in Asia and Africa suggest [24, 15]. The potential of local knowledge and practices could be encouraged through citizen initiatives and ecological stewardship [25-27], e.g. learning arenas connected to projects in which civil society groups, government, and volunteers collectively take part in environmental stewardship.

Those programs are showing that education and effective public participation seem to be crucial in facilitating ecosystem services in the long term and could support more formal governance and management of ecosystem services.

\section{CONCLUSION}

Fragile states are coping with rapid population growth, high climate change impacts vulnerability and serious political instability, which leads to social inequity, and ecological and economical degradation. Ecosystem-based adaptation concept uses ecosystem services to help people adapt to the various effects of climate change [12]. It is a strategy convenient for implementation in fragile states because it has multiple co-benefits, like cultural services and climate change mitigation.

To develop ecosystem services provision in the urbanized areas, it is necessary to preserve and upgrade ecosystem functioning on city scale. Due to the high level of governance informality and instability, conventional policy and regulatory measures used successfully to provide ecosystem services in cities elsewhere in the world may not be effective in the context of fragile states.

Through literature review, three main groups of actors are identified as responsible for ecosystem services provision in fragile states: government, international development partners and local communities.

Governments are weak and fragmented, and the crucial step for ecosystem services provision is generating 
continued, long-term political actions and extending municipal boundaries for greater control over land-use change, and introducing policies with wider, metropolitan or even regional impact [13].

While international resources and funds exist, there is a need for increasing access and transparency of process on governments procuring these opportunities [13].

Local knowledge and practices could have an important role in ecosystem services implementation and maintaining programs, and they can be integrated through strengthening and involving citizens. It is important to combine providing regulating ecosystem services for climate change adaptation with other ecosystem benefits, especially food provision, supporting knowledge systems and social relations, because it will be accepted, used and maintained in a better way within local community.

\section{REFERENCES}

[1] Lemma, A. (2012). Green Infrastructure in Fragile States, Overseas Development Institute.

[2] Andrade, A., Córdoba, R., Dave, R., Girot, P., Herrera-F, B., Munroe, R., Oglethorpe, J., Paaby, P., Pramova, E., Watson, J., \& Vergara, W. (2011). Draft principles and guidelines for integrating ecosystem-based approaches to adaptation in project and policy design. Policy brief, CATIE no. 46.

[3] The Fund for Peace. (2016). Fund for Peace Fragile States Index. (accessed in July 2016) http://library.fundforpeace.org/ library/fragilestatesindex-2016.pdf

[4] World Bank. (2009). World Development Report 2010: Development and Climate Change. Washington, DC: World Bank. https://doi.org/10.1596/978-0-8213-7987-5

[5] Wheeler, D. (2011). Quantifying vulnerability to climate change: implications for adaptation assistance. Center for Global Development Working Paper, (240). https://doi.org/10.2139/ssrn.1824611

[6] Wilkinson, C., Porter, L., \& Colding, J. (2010). Metropolitan Planning and Resilience Thinking: A Practitioner's Perspective. Critical Planning, 17, 2-20.

[7] EC (European Commission). (2015). Towards an EU research and innovation policy agenda for nature-based solutions and re-naturing cities. Final report of the Horizon 2020 expert group on 'nature-based solutions and re-naturing cities'. Directorate-General for Research and Innovation, EC, Luxembourg.

[8] Jones, H. P., Hole, D. G., \& Zavaleta, E. S. (2012). Harnessing nature to help people adapt to climate change. Nat Clim Chang, 2, 504-509. https://doi.org/10.1038/nclimate1463

[9] IPCC (Intergovernmental Panel on Climate Change). (2014). Climate change 2014: impacts, adaptation, and vulnerability. Cambridge University Press, Cambridge, UK.

[10] Wilkinson, C. (2012). Social-ecological resilience and planning. An interdisciplinary exploration. Ph.D. thesis, Stockholm University.

[11] Wu, J. (2014). Urban ecology and sustainability: the state-ofthe science and future directions. Landscape and Urban Planning, 125, 209-221. https://doi.org/10.1016/j.landurbplan.2014.01.018

[12] CBD (Convention on Biological Diversity). (2009). Identifying and Enhancing the Linkages between Biodiversity and Climate-Change Adaptation. Document code
UNEP/CBD/AHTEG/BD-CC-2/2/3. Convention on Biological Diversity (CBD). Montreal, Canada.

[13] Anderson, P. M., Okereke, C., Rudd, A., \& Parnell, S. (2013). Regional Assessment of Africa. In Urbanization, biodiversity and ecosystem services: Challenges and opportunities. Springer Netherlands, 453-459. https://doi.org/10.1007/978-94-007-7088-1_23

[14] Xiaokai Li, Marchand Marcel, \& Weihua Li. (2012). Grow in Concert with Nature: Green water defense for flood risk management in East Asia. An EASSD discussion paper. Washington DC: World Bank. http://wwwwds.worldbank.org/external/default/WDSContentServer/WD SP/IB/2013/01/24/000356161_20130124130230/Rendered/ PDF/NonAsciiFileName0.pdf https://doi.org/10.1596/978-0-8213-9588-2

[15] Schäffler, A. \& Swilling, M. (2013). Valuing green infrastructure in an urban environment under pressure-The Johannesburg case. Ecological Economics, 86, 246-257. https://doi.org/10.1016/j.ecolecon.2012.05.008

[16] MEA, M. E. A. (2005). Ecosystems and Human Well-being: General Synthesis.

[17] TEEB (2010), The Economics of Ecosystems and Biodiversity Ecological and Economic Foundations. Edited by Pushpam Kumar. Earthscan, London and Washington

[18] Haase, D., Frantzeskaki, N., \& Elmqvist, T. (2014). Ecosystem services in urban landscapes: practical applications and governance implications. Ambio, 43(4), 407412. https://doi.org/10.1007/s13280-014-0503-1

[19] Gómez-Baggethun, E., Gren, Å., Barton, D. N., Langemeyer, J., McPhearson, T., O'Farrell, P., ... \& Kremer, P. (2013). Urban ecosystem services. In Urbanization, biodiversity and ecosystem services: Challenges and opportunities. Springer Netherlands, 175-251. https://doi.org/10.1007/978-94-007-7088-1_11

[20] Asian Development Bank. (2012). Funded Project PIDs. (accessed in October 2012) http://www.adb.org/projects/ search $/ 21303$ ?page $=1$

[21] African Development Bank. (2012). Infrastructure Project Appraisal Reports. (accessed in October 2015) http://www.afdb.org/en/documents/project-operations/project -appraisal-reports/infrastructure/

[22] World Bank. (2009). World Development Report 2010: Development and Climate Change. Washington, DC: World Bank. https://doi.org/10.1596/978-0-8213-7987-5

[23] Lockwood, M., Worboys, G., \& Kothari, A. (Eds.). (2012). Managing protected areas: a global guide. Routledge.

[24] Cowles, E. R. (2015) Using the Social-Ecological Systems Framework to Evaluate Green Infrastructure: Coastal management case studies from Vietnam and Bangladesh The Hubert H. Humphrey School of Public Affairs, The University of Minnesota

[25] Krasny, M. E., Lundholm, C., Shava, S., Lee, E., \& Kobori, H. (2013). Urban landscapes as learning arenas for biodiversity and ecosystem services management. In Urbanization, biodiversity and ecosystem services: Challenges and opportunities. Springer Netherlands, 629664. https://doi.org/10.1007/978-94-007-7088-1_30

[26] Kohsaka, R., Pereira, H. M., Elmqvist, T., Chan, L., MorenoPeñaranda, R., Morimoto, Y., ... \& Cruz, C. S. (2013). Indicators for management of urban biodiversity and ecosystem services: City Biodiversity Index. In Urbanization, biodiversity and ecosystem services: challenges and opportunities. Springer Netherlands, 699-718. https://doi.org/10.1007/978-94-007-7088-1_32 
[27] Elmqvist, T., Fragkias, M., Goodness, J., Güneralp, B., Marcotullio, P. J., McDonald, R. I., ... \& Wilkinson, C. (2013). Stewardship of the biosphere in the urban era. In Urbanization, biodiversity and ecosystem services: Challenges and opportunities. Springer Netherlands, 719746. https://doi.org/10.1007/978-94-007-7088-1_33

Author's contact:

Antonija BOGADI, lecturer

University North

Trg Zarka Dolinara 1

48000 Koprivnica, Croatia

antonija.bogadi@gmail.com 